\title{
Analisis Video Comments to Likes Ratio Tiktok Pada 10 Brand Sepatu Terkenal di Dunia
}

\author{
I Komang Krisna Dwipayana \\ dikomangkrisna@gmail.com
}

\begin{abstract}
TikTok is a social media application launched by a Chinese company and created in September 2016. TikTok entered Indonesia at the end of 2017. TikTok allows users to create videos of 15 seconds, 60 seconds, and 3 minutes along with music, filters, speed, beautify, and timer. In Indonesia, there are 30.7 million active users, making Indonesia the country with the largest TikTok users in the world. The large number of active TikTok users in Indonesia can certainly provide an opportunity for brands to make the TikTok platform a social media marketing platform. There are 10 world-famous shoe brands that use TikTok as a marketing platform, namely: Vans Off The Wall, Nike, Puma, Converse, DC Shoes, Adidas, Reebok, Asics, New Balance (NB), and Skechers. The purpose of this study is to calculate the credibility of the TikTok account performance of 10 World Famous Shoe Brands. The method used for this research is quantitative exploratory method. The results of this study indicate that the Reebok Shoe Brand gets the first rank and the New Balance (NB) Shoe Brand gets the lowest rank, so both of them have good account performance credibility.
\end{abstract}

\begin{abstract}
ABSTRAK
TikTok adalah suatu aplikasi sosial media yang diluncurkan oleh perusahaan asal Tiongkok dan dibuat pada September 2016. TikTok masuk Indonesia pada akhir tahun 2017. TikTok memungkinkan penggunanya membuat video berdurasi 15 detik, 60 detik, dan 3 menit yang disertai dengan musik, filter, kecepatan, mempercantik, dan timer. Di Indonesia terdapat 30,7 juta pengguna yang aktif sehingga menjadikan Indonesia sebagai negara dengan pengguna TikTok terbesar di dunia. Maraknya jumlah pengguna TikTok yang aktif di Indonesia tentu dapat memberikan peluang bagi brand untuk menjadikan platform TikTok sebagai platform social media marketing. Adapun 10 brand sepatu yang terkenal didunia yang memanfaatkan TikTok sebagai platform marketing, yaitu : Vans Off The Wall, Nike, Puma, Converse, DC Shoes, Adidas, Reebok, Asics, New Balance (NB), dan Skechers. Tujuan dari penelitian ini yaitu untuk menghitung kredibilitas dari performa akun TikTok 10 Brand Sepatu Yang Terkenal Didunia. Metode yang digunakan untuk penelitian ini yaitu metode eksploratif kuantitatif. Hasil dari penelitian ini menunjukan bahwa Brand Sepatu Reebok mendapatkan peringkat pertama dan Brand Sepatu New Balancce (NB) mendapatkan pringkat terendah, maka keduanya sama-sama memiliki kredibilitas performa akun yang baik.
\end{abstract}

Keyword : Credibility Account TikTok ; Social Media Marketing ; Social Media TikTok ; Video Comments to Likes Ratio ; Brand Sepatu Terkenal di Dunia

\section{PENDAHULUAN}

Salah satu aplikasi video yang sering di gunakan oleh masyarakat dan sekarang ini sedang terkenal adalah aplikasi Tiktok. Aplikasi ini dibuat oleh seorang asal Tiongkok yaitu Zhang Yiming. Tiktok yang kita kenal seperti sekarang awalnya tidak muncul sebagai Tiktok. Pada September 2016 perusahaan asal Cina yakni Byte Dance meluncurkan aplikasi video pendek bernama Douyin. Dalam waktu 1 tahun Douyin memiliki 100 juta pengguna dan 1 miliar tayangan video setiap hari. Akibat meroketnya popularitas Douyin melakukan ekspansi ke luar Cina dengan nama baru yang lebih dikenal yaitu Tiktok. Meskipun Negara Cina yang membuat aplikasi Tiktok tetapi bukan mereka yang banyak mengunduh dan menggunakan 
aplikasi tersebut. Aplikasi Tiktok ini memberikan efek-efek spesial untuk video pendek sehingga terlihat menarik dan dapat ditonton oleh siapa saja selama masih memiliki jaringan internet. Semakin unik video yang dibagikan maka semakin banyak pula yang melihat video tersebut. Hal ini cenderung menyebabkan pengguna Tiktok berani melakukan hal apapun demi meraih popularitas. Selain itu aplikasi untuk membuat video pendek ini juga dilengkapi dengan dukungan musik yang cukup banyak sehingga para pengguna bisa membuat video pendek disertai dengan tarian, gaya bebas, bernyanyi dan masih banyak lagi. Hal ini bisa mendorong kreativitas seseorang untuk membuat video pendek sebagus mungkin dan menarik perhatian banyak orang. Dengan adanya aplikasi Tiktok dapat memberikan hiburan bagi setiap orang untuk menghilangkan rasa lelah dan rasa bosan bahkan pengguna Tiktok bisa mengeluarkan banyak ekspresi jika sedang menggunakan dan melihat video-video di Tiktok seperti mengeluarkan ekspresi senang,sedih,gembira,kecewa,marah dan berbagai ekspresi lainnya karena dalam aplikasi tersebut setiap orang dapat melihat berbagai video dengan ekspresi video yang berbeda-beda (Wanimbo, Tumengkol, and Tumiwa 2021).

Tidak hanya melihat video yang di buat oleh orang lain, kita juga bisa membuat video Tiktok sendiri dengan menirukan gerakan yang di buat oleh orang lain. Contohnya bernyanyi bersama dengan pengguna Tiktok, mengikuti tantangan dari orang lain, membuat ide-ide yang kreatif dan masih banyak lagi. pembuat aplikasi Tiktok bisa memahami keinginan dan hal-hal yang sering dilakukan oleh para pengguna sehingga bisa melakukan sugesti yang baik dan bisa meningkatkan peminat yang menggunakan aplikasi Tiktok ini. masyarakat juga mengklaim bahwa aplikasi ini bisa melakukan pengenalan wajah dengan kecepatan yang tinggi, yang akan disugestikan pada fitur wajah yang menarik. Bukan hanya itu saja aplikasi ini juga menyediakan backsound musik dari berbagai artis yang terkenal dari berbagai kategori musik dan bisa membuat video menjadi lebih menarik untuk dilihat dan didengar (Wanimbo, Tumengkol, and Tumiwa 2021).

Aplikasi Tik Tok pernah menjadi persoalan yang pro dan kontra di masyarakat. Bahkan, aplikasi tersebut pernah di blokir di Indonesia. Pada Selasa, 3 Juli 2018, Kominfo mengumumkan secara resmi pemblokiran Tik Tok. Kominfo memblokir delapan nama domain atau DNS yang terkait dengan Tik Tok. Namun, hal tersebut tidak bertahan lama dan aplikasi Tik Tok kembali bisa diakses oleh masyarakat. terdapat lebih dari 10 juta orang di Indonesia yang sebagian besar adalah anak usia sekolah (pelajar), sehingga terlihat bahwa aplikasi Tik Tok merupakan aplikasi yang disukai dan diminati oleh generasi milenial yang sebagian besar adalah anak usia sekolah. Hal ini harus disikapi secara baik oleh masyarakat, aplikasi Tik Tok harus digunakan untuk keperluan yang bermanfaat, seperti kebutuhan edukasi dan pembelajaran sehingga stigma negatif yang ada di aplikasi ini dapat terbantahkan (Nugroho, Supriyono, and Nugraha 2021).

\section{TINJAUAN PUSTAKA}

Aplikasi TikTok merupakan atau jaringan media sosial yang digunakan oleh penggunanya untuk membuat video pendek dengan durasi maksimal 60 detik. Dengan Aplikasi TikTok Pengguna dapat melakukan berbagai ekspresi, gaya, gerakan maupun tarian (Susilowati,2018) dengan backsound musik yang sudah tersedia TikTok atau membuatnya sendiri sesuai dengan kreavifitas pengguna (Dewanta 2020). 
Tiktok mulai kembali digandrungi serta dianggap aplikasi yang positif oleh para penggunanya sejak masa pandemi Covid-19 saat pemerintah menetapkan PSBB yang mengharuskan seluruh masyarakat tetap produktif dirumah. Kemudahan mendapatkan dan cara menggunakannya membuat tiktok dipilih sebagai media yang digunakan untuk menuangkan kebosanan masyarakat khususnya dikalangan generasi Z, Aplikasi tersebut memiliki banyak konten video yang bisa dibuat dengan sangat mudah. Tak cuma melihat serta menirukan, pengguna bisa membuat video dengan cara mereka sendiri. Mereka dapat menuangkan ide-ide kreatif mereka agar video tersebut memiliki viewers/likers yang tinggi dan dapat menjadi contoh pengguna lain untuk membuat video. Hal tersebut membuat tiktok juga bisa melatih penggunanya untuk menumbuhakan pola pikir kreatif (Arciniegas Paspuel, O. G., Álvarez Hernández, S. R., Castro Morales, L. G., \& Maldonado Gudiño, C. W. (2021). Inte- ligencia emocional en estudiantes de la Universidad Autónoma de Los Andes. Revista Conrado, 17(78) 2021).

Penelitian ini terinspirasi dari karya Michael Hartono (2019) tentang aplikasi sosial video pendek ini (TikTok) yang dapat membantu para user untuk bisa menjadi content creator, dikarenakan aplikasi ini memiliki dukungan musik yang banyak sehingga penggunanya dapat melakukan performanya dengan tarian, gaya bebas, yang dapat mendorong kreativitas penggunanya (Bulele and Wibowo 2020).

Hasil dari pembuatan konten video yang telah dikreasikan pengguna dalam aplikasi Tik Tok dengan mudah dishare ke berbagai platform media sosial lainnya, sehingga memungkinkan para penggunanya bisa saling bertukar konten. Bahkan menurut Putra15, dengan dukungan teknologi mutakhir, aplikasi Tik Tok bisa memahami hal-hal yang biasanya sering dilakukan para penggunanya, sehingga dapat menyesuaikan dan meningkatkan permintaan pasar. Hal ini dikarenakan ragam layanan efek yang bisa digunakan secara instan (Fanaqi 2021).

Untuk menggunakan aplikasi tersebut sangatlah mudah, dengan hanya melihat, menghafal, dan menirukan apa yang ada didalam aplikasi TikTok tersebut. Setelah mereka mereka memilih video yang ingin mereka buat, dengan memastikan salah satu video yang dipilih sesuai selera dengan menekan tombol bergambar kamera video dan nantinya akan diproses beberapa detik. Musik sudah di proses barulah mereka bisa membuat video yang mereka pilih dan sudah mereka hafalkan (Priambodo 2018).

Di Indonesia, TikTok sempat mengalami masa pemblokiran dan pemantauan sejak 3 Juli 2018. Namun dengan memenuhi 9 dari 10 syarat yang diberikan Kementerian Komunikasi dan Informatika (Kominfo), pada 3 Juli 2018 TikTok mulai diizinkan lagi di Indonesia, dan sejak saat itu aplikasi TikTok mengalami peningkatan jumlah pengguna. Dilansir dari Statista (Juni.2020) jumlah pengguna TikTok di Indonesia mencapai 30,7 juta pengguna. Dari angka tersebut menempatkan Indonesia sebagai negara keempat dengan pengguna TikTok tertinggi di dunia, menyusul India di peringkatpertama, Amerika Serikat, dan Brasil (Aldila Safitri, Rahmadhany, and Irwansyah 2021). 
Perilaku Generasi Z dalam menggunakan TikTok sebagai media penyaluran edukasi dan aktivisme merupakan suatu perilaku manusia dalam periode umur remaja yang inovatif dan kreatif. Upaya intervensi dalam perilaku ini adalah mengubah cara pandang media sosial yang selalu di anggap negatif karena perilaku adikitif yang mampu dimunculkan oleh media sosial tersebut. Namun, kreativitas yang disajikan dalam TikTok oleh para pengguna merupakan salah satu cara yang dapat mengubah perspektif tersebut menjadi positif. Adanya perspektif baru ini mampu mengubah individu untuk memiliki pemahaman lebih baik terhadap penggunaan TikTok karena adanya perkembangan diri dari hasil interpretasi interaksi sosial antar penonton dan pencipta konten (Firamadhina and Krisnani 2021).

\section{METODE PENELITIAN}

Metode penelitian kali ini menggunakan metode kuantitatif. Penelitian kuantitatif melihat suatu fenomena sebagai perilaku sosial yang dapat diukur, diamati dan dikonsepkan yang ada pada masyarakat. Sedangkan paradigma yang digunakan kali ini yakni paradigma positivisme yang bebas nilai serta memiliki penilaian yang subjektif yang mana melihat suatu fenomena berdasarkan hal-hal yang tampak (Adawiyah 2020). Peneliti telah menetapkan karakteristik tertentu untuk dipelajari sehingga dapat mengambil suatu kesimpulan yang ada melalui analisis media sosial. Penelitian ini bertujuan untuk mengetahui variabel-variabel pada media sosial Tiktok yang nantinya akan dirumuskan menjadi rasio-rasio (I Putu Hendika Permana and Ni Putu Suci Meinarni 2021). Akun Tiktok yang dapat dianalisis harus memenuhi persyaratan teknis pengaturan Tiktok yang akan dianalisis, yaitu:

1. Merupakan akun dengan status publik atau non-private sehingga dapat diakses tanpa harus meminta konfirmasi dari pemilik akun.

2. Kolom komentar tidak dinonaktifkan sehingga kolom komentar menentukan angka yang menunjukkan jumlah komentar pada sebuah postingan.

3. Pemilik akun memberikan kebebasan kepada pengguna lain untuk dapat membagikan (share) postingan konten video yang dibuat dengan pengguna lain. Penelitian ini bertujuan untuk menjadi acuan.

Berikut adalah proses pencarian variabel di Tiktok.

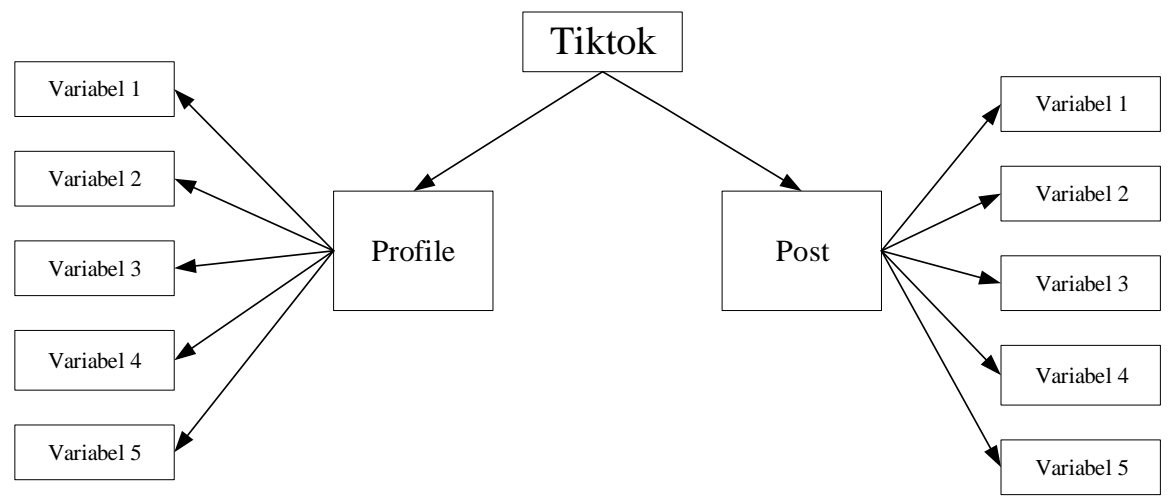

Gambar 1 Mencari Variabel di Tiktok (Sumber: Self-Processed Image)

Rasio adalah perbandingan suatu bilangan dengan bilangan lain yang membentuk suatu hubungan. Rasio memerlukan minimal 2 variabel yang dibandingkan untuk menghasilkan 
suatu nilai dan dinyatakan dalam persentase. Kemudian variabel-variabel tersebut akan diuji relevansinya sehingga dapat ditentukan apakah perbandingan antara kedua variabel tersebut dapat dikategorikan sebagai rasio.

Relevansi rasio ditunjukkan dengan menganalisis pengaruh rasio terhadap penilaian akun Tiktok yang dianalisis. Rasio termasuk dalam kategori tidak relevan jika perbandingan antara 2 variabel memiliki kondisi sebagai berikut:

1. Perbandingan antara variabel yang sama.

2. Variabel pertama cenderung memiliki nilai yang besar dibandingkan dengan variabel kedua.

3. Kedua variabel tersebut tidak dipengaruhi atau ditentukan oleh publik.

4. Kedua variabel tersebut tidak sesuai atau tidak tepat untuk dibandingkan.

Penelitian ini menggunakan operasional instrumen dengan menggunakan karakteristik pada Media Sosial TikTok dan Kepercayaan Diri masing-masing sebanyak lima elemen. Disusun berdasarkan aspek dan indikator. Skala yang digunakan menggunakan model video comments to likes. Skala video comments to likes digunakan untuk mengukur sikap, pendapat, dan persepsi seseorang tentang fenomena sosial (Adawiyah 2020).

\section{HASIL DAN PEMBAHASAN}

Akun TikTok dari 10 brand sepatu terkenal didunia, diantaranya :

\section{Vans Off The Wall}

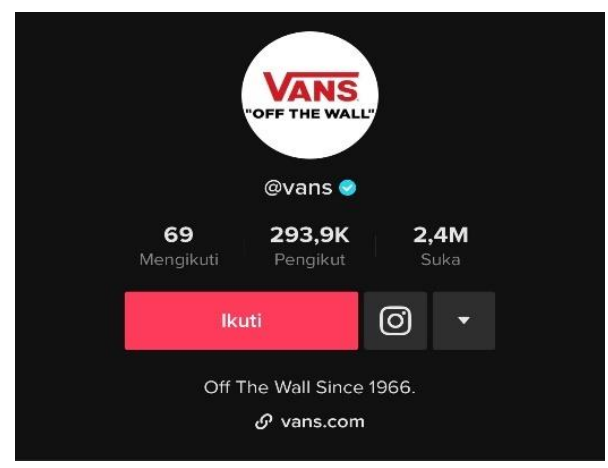

Gambar 1. Akun TikTok Vans Off The Wall

Sumber : https://vt.tiktok.com/ZSeFqJ5WN/ (akses pada 21-10-2021)

\section{Nike}




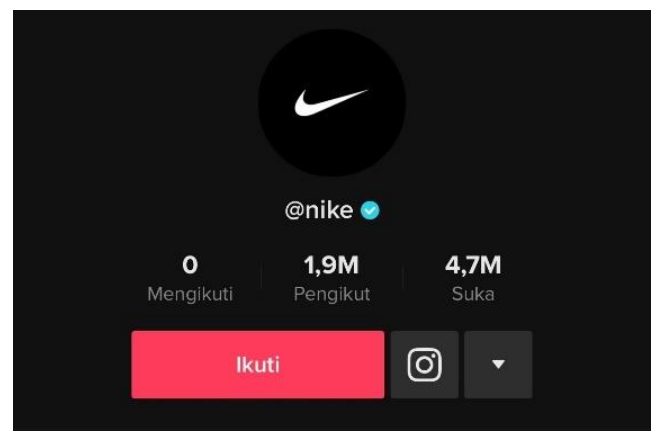

Gambar 2. Akun TikTok Nike

Sumber : https://vt.tiktok.com/ZSeFVvh3K/ (akses pada 21-10-2021)

\section{Puma}

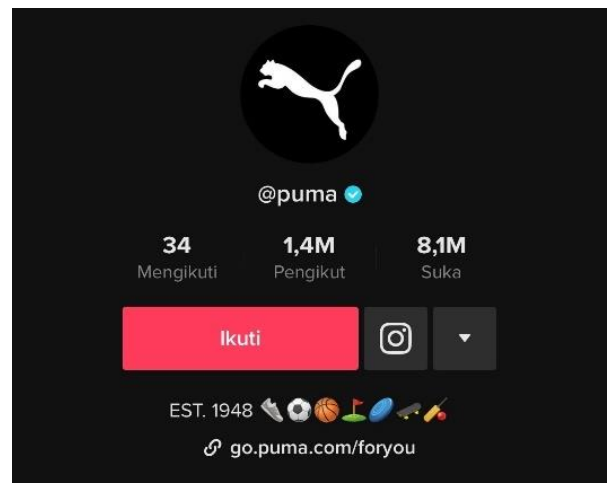

Gambar 3. Akun TikTok Puma

Sumber : https://vt.tiktok.com/ZSeFVwk8t/ (akses pada 21-10-2021)

\section{Converse}

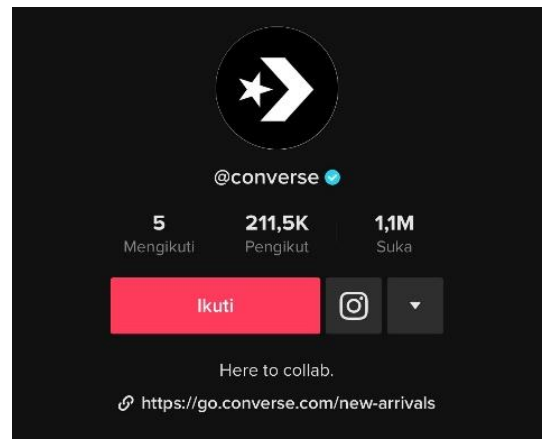

Gambar 4. Akun Tiktok Converse

Sumber : https://vt.tiktok.com/ZSeFV4Ljm/ (akses pada 21-10-2021)

\section{DC Shoes}




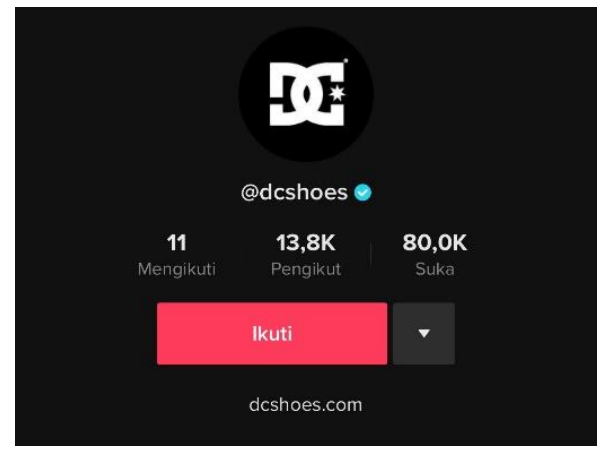

Gambar 5. Akun TikTok DC Shoes

Sumber : https://vt.tiktok.com/ZSeFqJrTf/ (akses pada 21-10-2021)

\section{Adidas}

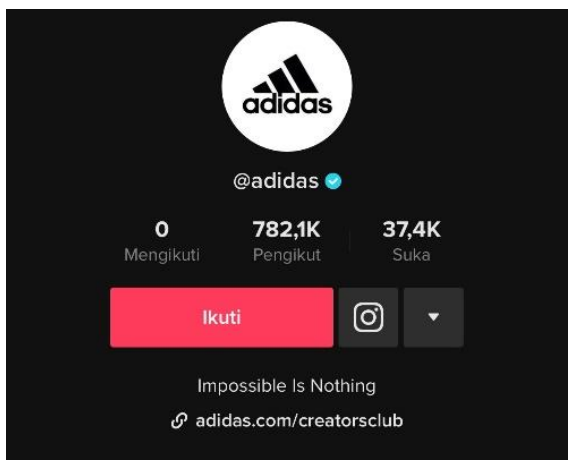

Gambar 6 Akun TikTok Adidas

Sumber : https://vt.tiktok.com/ZSeFV3dQJ/ (akses pada 21-10-2021)

\section{Reebok}

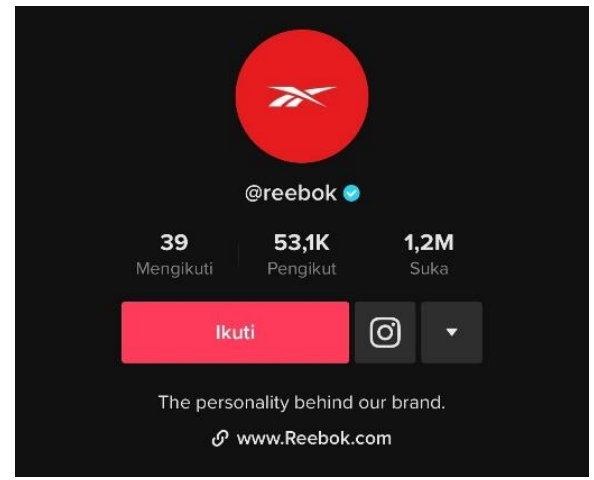

Gambar 7. Akun TikTok Reebok

Sumber : https://vt.tiktok.com/ZSeFV3aoQ/ (akses pada 21-10-2021)

\section{Asics}




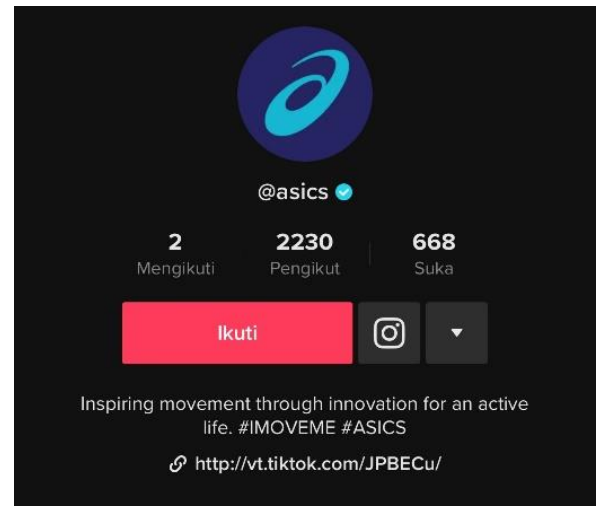

Gambar 8. Akun TikTok Asics

Sumber : https://vt.tiktok.com/ZSeFVXwR7/ (akses pada 21-10-2021)

\section{New Balance (NB)}

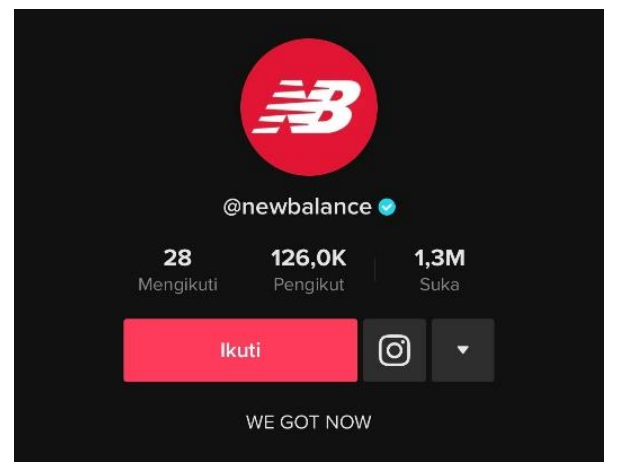

Gambar 9. Akun TikTok New Balance (NB)

Sumber : https://vt.tiktok.com/ZSeFVcuEn/ (akses pada 21-10-2021)

\section{Skechers}

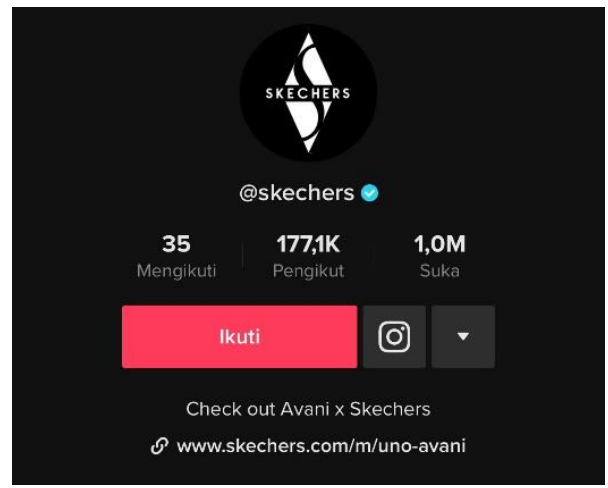

Gambar 10. Akun TikTok Skechers

Sumber : https://vt.tiktok.com/ZSeFV3Enf/ (akses pada 21-10-2021)

Dari kesepuluh akun 10 Brand Sepatu Terkenal di Dunia, peneliti menemukan nilai dari masing-masing variabel yang ada untuk menghitung rasio video comments to likes dari setiap akun. Pada akun TikTok terdapat 7 variabel, diantaranya yaitu : 
1. Likes

2. Followers

3. Following

4. Video Likes

5. Video Comments

6. Video Share

7. Video Views

Dari ketujuh variabel tersebut peneliti hanya fokus untuk menemukan hasil dari 2 variabel, yaitu :

\section{Video Comments}

2. Likes

Dari kedua variabel tersebut kemudian dianalisa sehingga menemukan nilai rata-rata dari variabel video comments dan variabel likes. Untuk menghitung nilai rata-rata dari variabel video comments dan variabel likes yaitu dengan cara mengambil minimal 10 postingan kemudian di hitung sehingga menemukan nilai rata-rata dari masing-masing variabel. Berikut merupakan tabel nilai rata-rata dari masing-masing brand sepatu yang terkenal di dunia, yaitu:

Tabel 1. Analisa Nilai Rata-Rata Nilai Variabel Video Comments dan Likes Akun TikTok Vans Off The Wall

\begin{tabular}{|c|c|c|}
\hline No & Vidio Comments & Likes \\
\hline 1 & 24 & 608 \\
\hline 2 & 21 & 540 \\
\hline 3 & 8 & 539 \\
\hline 4 & 66 & 3,322 \\
\hline 5 & 17 & 447 \\
\hline 6 & 19 & 701 \\
\hline 7 & 7 & 481 \\
\hline 8 & 27 & 1,496 \\
\hline 9 & 54 & 3,309 \\
\hline 10 & 77 & 2,151 \\
\hline Total & $\mathbf{3 2}$ & $\mathbf{1 , 3 5 9}$ \\
\hline \multicolumn{2}{|c|}{ Sumber : Pengolah Data Excel } \\
\hline
\end{tabular}

Tabel 2. Analisa Nilai Rata-Rata Nilai Variabel Video Comments dan Likes Akun TikTok Nike

\begin{tabular}{|c|c|c|}
\hline No & Vidio Comments & Likes \\
\hline 1 & 42 & 1,087 \\
\hline
\end{tabular}




\begin{tabular}{|c|c|c|}
2 & 41 & 573 \\
\hline 3 & 29 & 1,185 \\
\hline 4 & 39 & 2,634 \\
\hline 5 & 46 & 2,821 \\
\hline 6 & 44 & 1,740 \\
\hline 7 & 35 & 1,895 \\
\hline 8 & 29 & 2,298 \\
\hline 9 & 28 & 5,955 \\
\hline 10 & 34 & 2,060 \\
\hline Total & $\mathbf{3 7}$ & $\mathbf{2 , 2 2 5}$ \\
\hline \multicolumn{2}{|c|}{ Sumber : Pengolah Data Excel } \\
\hline
\end{tabular}

Tabel 3. Analisa Nilai Rata-Rata Nilai Variabel Video Comments dan Likes Akun TikTok Puma

\begin{tabular}{|c|c|c|}
\hline No & Vidio Comments & Likes \\
\hline 1 & 30 & 1,180 \\
\hline 2 & 694 & 22,400 \\
\hline 3 & 48 & 695 \\
\hline 4 & 63 & 2,131 \\
\hline 5 & 37 & 2,863 \\
\hline 6 & 40 & 10,000 \\
\hline 7 & 34 & 7,740 \\
\hline 8 & 46 & 4,615 \\
\hline 9 & 276 & 35,600 \\
\hline 10 & 26 & 2,657 \\
\hline Total & $\mathbf{1 2 9}$ & $\mathbf{8 , 9 8 8}$ \\
\hline
\end{tabular}

Sumber : Pengolah Data Excel

Tabel 4. Analisa Nilai Rata-Rata Nilai Variabel Video Comments dan Likes Akun TikTok Converse

\begin{tabular}{|c|c|c|}
\hline No & Vidio Comments & Likes \\
\hline 1 & 33 & 689 \\
\hline 2 & 38 & 7,460 \\
\hline 3 & 16 & 733 \\
\hline 4 & 11 & 635 \\
\hline 5 & 25 & 1,984 \\
\hline 6 & 16 & 2,628 \\
\hline 7 & 20 & 995 \\
\hline 8 & 17 & 1,307 \\
\hline 9 & 18 & 1,890 \\
\hline 10 & 42 & 1,889 \\
\hline Total & $\mathbf{2 4}$ & $\mathbf{2 , 0 2 1}$ \\
\hline
\end{tabular}

Sumber : Pengolah Data Excel

Tabel 5. Analisa Nilai Rata-Rata Nilai Variabel Video Comments dan Likes Akun TikTok DC Shoes

\begin{tabular}{|c|c|c|}
\hline No & Vidio Comments & Likes \\
\hline 1 & 2 & 66 \\
\hline
\end{tabular}




\begin{tabular}{|c|c|c|}
2 & 4 & 484 \\
\hline 3 & 34 & 2,650 \\
\hline 4 & 12 & 521 \\
\hline 5 & 3 & 353 \\
\hline 6 & 58 & 7,906 \\
\hline 7 & 13 & 987 \\
\hline 8 & 8 & 1,309 \\
\hline 9 & 28 & 1,503 \\
\hline 10 & 2 & 233 \\
\hline Total & $\mathbf{1 6}$ & $\mathbf{1 , 6 0 1}$ \\
\hline \multicolumn{2}{|c|}{ Sumber : Pengolah Data Excel } \\
\hline
\end{tabular}

Tabel 6. Analisa Nilai Rata-Rata Nilai Variabel Video Comments dan Likes Akun TikTok Adidas

\begin{tabular}{|c|c|c|}
\hline No & Vidio Comments & Likes \\
\hline 1 & 70 & 6,385 \\
\hline 2 & 106 & 2,977 \\
\hline 3 & 461 & 7,911 \\
\hline 4 & 909 & 16,300 \\
\hline 5 & 2,268 & 255,700 \\
\hline 6 & 3,642 & 628,300 \\
\hline 7 & 221 & 54,700 \\
\hline 8 & 422 & 27,300 \\
\hline 9 & 27,900 & 295,400 \\
\hline 10 & 2,445 & 622,900 \\
\hline Total & $\mathbf{3 , 8 4 4}$ & $\mathbf{1 9 1 , 7 8 7}$ \\
\hline
\end{tabular}

Sumber : Pengolah Data Excel

Tabel 7. Analisa Nilai Rata-Rata Nilai Variabel Video Comments dan Likes Akun TikTok Reebok

\begin{tabular}{|c|c|c|}
\hline No & Vidio Comments & Likes \\
\hline 1 & 13 & 109 \\
\hline 2 & 3 & 59 \\
\hline 3 & 15 & 58 \\
\hline 4 & 12 & 196 \\
\hline 5 & 5 & 109 \\
\hline 6 & 5 & 80 \\
\hline 7 & 5 & 95 \\
\hline 8 & 7 & 93 \\
\hline 9 & 8 & 92 \\
\hline 10 & 27 & 420 \\
\hline Total & $\mathbf{1 0}$ & $\mathbf{1 3 1}$ \\
\hline
\end{tabular}

Sumber : Pengolah Data Excel

Tabel 8. Analisa Nilai Rata-Rata Nilai Variabel Video Comments dan Likes Akun TikTok Asics

\begin{tabular}{|c|c|c|}
\hline No & Vidio Comments & Likes \\
\hline 1 & 42 & 656 \\
\hline
\end{tabular}




\begin{tabular}{|c|c|c|}
2 & 10 & 380 \\
\hline 3 & 8 & 249 \\
\hline 4 & 77 & 1,032 \\
\hline 5 & 22 & 1,561 \\
\hline 6 & 363 & 131,200 \\
\hline 7 & 50 & 3,431 \\
\hline 8 & 330 & 13,300 \\
\hline 9 & 37 & 342 \\
\hline 10 & 36 & 4,319 \\
\hline Total & $\mathbf{9 8}$ & $\mathbf{1 5 , 6 4 7}$ \\
\hline \multicolumn{2}{|c|}{ Sumber : Pengolah Data Excel } \\
\hline
\end{tabular}

Tabel 9. Analisa Nilai Rata-Rata Nilai Variabel Video Comments dan Likes Akun TikTok New Balance (NB)

\begin{tabular}{|c|c|c|}
\hline No & Vidio Comments & Likes \\
\hline 1 & 37 & 29,300 \\
\hline 2 & 260 & 100,400 \\
\hline 3 & 323 & 120,000 \\
\hline 4 & 117 & 68,900 \\
\hline 5 & 32 & 25,500 \\
\hline 6 & 110 & 38,000 \\
\hline 7 & 293 & 64,800 \\
\hline 8 & 565 & 204,000 \\
\hline 9 & 1,201 & 349,900 \\
\hline 10 & 601 & 307,700 \\
\hline Total & $\mathbf{3 5 4}$ & $\mathbf{1 3 0 , 8 5 0}$ \\
\hline \multicolumn{3}{|c|}{ Sumber : Pengolah Data Excel } \\
\hline
\end{tabular}

Tabel 10. Analisa Nilai Rata-Rata Nilai Variabel Video Comments dan Likes Akun TikTok Skechers

\begin{tabular}{|c|c|c|}
\hline No & Vidio Comments & Likes \\
\hline 1 & 24 & 255 \\
\hline 2 & 23 & 251 \\
\hline 3 & 161 & 1,067 \\
\hline 4 & 404 & 60,100 \\
\hline 5 & 162 & 10,100 \\
\hline 6 & 39 & 1,405 \\
\hline 7 & 102 & 15,800 \\
\hline 8 & 80 & 5,220 \\
\hline 9 & 24 & 2,222 \\
\hline 10 & 184 & 6,843 \\
\hline Total & $\mathbf{1 2 0}$ & $\mathbf{1 0 , 3 2 6}$ \\
\hline
\end{tabular}

Sumber : Pengolah Data Excel

Setelah menghitung nilai rata-rata tersebut, maka akan menemukan hasil akhir nilai rata-rata dari variabel video comments dan likes

Tabel 11. Nilai Variabel Pada Akun TikTok 10 Brand Sepatu Terkenal di Dunia

\begin{tabular}{|c|c|c|}
\hline 10 Brand Sepatu & Variabel & Nilai \\
\hline
\end{tabular}




\begin{tabular}{|c|c|c|}
\hline \multirow{2}{*}{ Vans Off The Wall } & Vidieo Comments & 32 \\
\hline & Likes & 1.359 \\
\hline \multirow{2}{*}{ Nike } & Vidieo Comments & 37 \\
\hline & Likes & 2.225 \\
\hline \multirow{2}{*}{ Puma } & Vidieo Comments & 129 \\
\hline & Likes & 8.988 \\
\hline \multirow{2}{*}{ Converse } & Vidieo Comments & 24 \\
\hline & Likes & 2.021 \\
\hline \multirow{2}{*}{ DC Shoes } & Vidieo Comments & 16 \\
\hline & Likes & 1.601 \\
\hline \multirow{2}{*}{ Adidas } & Vidieo Comments & 8.844 \\
\hline & Likes & 191.787 \\
\hline \multirow{2}{*}{ Reebok } & Vidieo Comments & 10 \\
\hline & Likes & 131 \\
\hline \multirow{2}{*}{ Asics } & Vidieo Comments & 98 \\
\hline & Likes & 15.647 \\
\hline \multirow{2}{*}{ New Balance (NB) } & Vidieo Comments & 354 \\
\hline & Likes & 130.85 \\
\hline \multirow{2}{*}{ Skechers } & Vidieo Comments & 120 \\
\hline & Likes & 10.326 \\
\hline
\end{tabular}

Pada akun TikTok terdapat 17 rasio yang relevan digunakan untuk mengukur kredibilitas pada masing-masing akun. Namun pada penelitian kali ini hanya berfokus untuk menghitung Video Comments to Likes Ratio. Untuk menghitung kredibilitas dari masingmasing akun TikTok setiap Brand Sepatu, peneliti menghitung dengan cara : variabel 1 akan dibagi dengan variabel 2, sehingga ditemukan hasil analisisa dari rasio tersebut.

Tabel 12. Hasil Perhitungan Rasio Akun TikTok

\begin{tabular}{|c|l|c|c|}
\hline No & \multicolumn{1}{|c|}{ 10 Brand Sepatu } & Nilai & \multicolumn{1}{c|}{ Ratio } \\
\hline 1 & Vans Off The Wall & 0.023546726 & Vidieo Comments to Likes Ratio \\
\hline 2 & Nike & 0.016629213 & Vidieo Comments to Likes Ratio \\
\hline 3 & Puma & 0.01435247 & Vidieo Comments to Likes Ratio \\
\hline 4 & Converse & 0.011875309 & Vidieo Comments to Likes Ratio \\
\hline 5 & DC Shoes & 0.009993754 & Vidieo Comments to Likes Ratio \\
\hline 6 & Adidas & 0.020043069 & Vidieo Comments to Likes Ratio \\
\hline 7 & Reebok & 0.076335878 & Vidieo Comments to Likes Ratio \\
\hline 8 & Asics & 0.006263181 & Vidieo Comments to Likes Ratio \\
\hline 9 & New Balance (NB) & 0.002705388 & Vidieo Comments to Likes Ratio \\
\hline 10 & Skechers & 0.002705388 & Vidieo Comments to Likes Ratio \\
\hline
\end{tabular}

Video Comments to Likes Ratio memiliki karakteristik yang tinggi, artinya semakin tinggi nilai yang dihasilkan maka semakin baik kredibilitas dari performa akun tersebut. Untuk memberikan peringkat pada masing-masing Brand Sepatu, peneliti memberikan angka 10 kepada brand yang mendapatkan nilai terendah dan angka 1 untuk brand sepatu yang 
mendapatkan nilai tertinggi. Berikut merupakan tabel urutan nilai yang dihasilkan oleh masingmasing brand sepatu.

Tabel 13. Nilai Rasio Akun TikTok 10 Brand Sepatu Terkenal di Dunia

\begin{tabular}{|l|c|l|}
\hline \multicolumn{1}{|c|}{ 10 Brand Sepatu } & Peringkat & \multicolumn{1}{c|}{ Ratio } \\
\hline Vans Off The Wall & 2 & Vidieo Comments to Likes Ratio \\
\hline Nike & 4 & Vidieo Comments to Likes Ratio \\
\hline Puma & 5 & Vidieo Comments to Likes Ratio \\
\hline Converse & 6 & Vidieo Comments to Likes Ratio \\
\hline DC Shoes & 8 & Vidieo Comments to Likes Ratio \\
\hline Adidas & 3 & Vidieo Comments to Likes Ratio \\
\hline Reebok & 1 & Vidieo Comments to Likes Ratio \\
\hline Asics & 9 & Vidieo Comments to Likes Ratio \\
\hline New Balance (NB) & 10 & Vidieo Comments to Likes Ratio \\
\hline Skechers & 7 & Vidieo Comments to Likes Ratio \\
\hline
\end{tabular}

Dari Tabel Nilai Rasio Akun TikTok 10 Brand Sepatu Terkenal di Dunia dapat simpulkan bahwa New Balance (NB) mendapatkan nilai terendah untuk rasio Video Comments to Likes. Sedangkan akun TikTok Reebok mendapatkan nilai tertinggi untuk rasio ini. Jadi, pada penelitian ini New Balance (NB) memiliki kredibilitas performa yang lebih baik dibandingkan dengan brand sepatu yang lainnya.

\section{KESIMPULAN}

Tujuan dari penelitian ini adalah mengetahui kredibilitas performa dari akun TikTok 10 Brand Sepatu Terkenal di Dunia menggunakan Video Comments to Likes Ratio. 10 Brand Sepatu Terkenal di Dunia tersebut diantaranya :Vans Off The Wall, Nike, Puma, Converse, DC Shoes, Adidas, Reebok, Asics, New Balance (NB), dan Skechers. Dari 10 Brand Sepatu Terkenal di Dunia, Peringkat Pertama diraih oleh brand Reebok dengan nilai tertinggi yaitu 0.076335878

1. Peringkat kedua diraih oleh brand Vans Off The Wall dengan nilai 0.023546726

2. Peringkat ketiga diraih oleh brand Adidas dengan nilai 0.020043069

3. Peringkat keempat diraih oleh brand Nike dengan nilai 0.016629213

4. Peringkat kelima diraih oleh brand Puma dengan nilai 0.01435247

5. Peringkat keenam diraih oleh brand Converse dengan nilai 0.011875309

6. Peringkat ketujuh diraih oleh brand Skechers dengan nilai 0.01162115

7. Peringkat kedelapan diraih oleh brand DC Shoes dengan nilai 0.009993754

8. Peringkat kesembilan diraih oleh brand Asics dengan nilai 0.006263181

9. Peringkat kesepuluh diraih oleh brand New Balance (NB) dengan nilai terendah yaitu 0.002705388

\section{Daftar Pustaka}

Adawiyah, Dwi Putri Robiatul. 2020. "Pengaruh Penggunaan Aplikasi TikTok Terhadap Kepercayaan Diri Remaja Di Kabupaten Sampang.” Jurnal Komunikasi 14 (2): 135-48. https://doi.org/10.21107/ilkom.v14i2.7504. 
Aldila Safitri, Anggi, Anissa Rahmadhany, and Irwansyah Irwansyah. 2021. "Penerapan Teori Penetrasi Sosial Pada Media Sosial: Pengaruh Pengungkapan Jati Diri Melalui TikTok Terhadap Penilaian Sosial." Jurnal Teknologi Dan Sistem Informasi Bisnis 3 (1): 1-9. https://doi.org/10.47233/jteksis.v3i1.180.

Arciniegas Paspuel, O. G., Álvarez Hernández, S. R., Castro Morales, L. G., \& Maldonado Gudiño, C. W. (2021). Inte- ligencia emocional en estudiantes de la Universidad Autónoma de Los Andes. Revista Conrado, 17(78), 127-133. 2021. “No 主観的健康感を中心とした在宅高齢者 における 健康関連指標に関する共分散構造分析Title” 6 (9): 6.

Bulele, Yohana Noni, and Tony Wibowo. 2020. "Analisis Fenomena Sosial Media Dan Kaum Milenial: Studi Kasus Tiktok." Conference on Business, Social Sciences and Innovation Technology 1 (1): 565-72. http://journal.uib.ac.id/index.php/cbssit.

Dewanta, Anak Agung Ngurah Bagus Janitra. 2020. "Pemanfaatan Aplikasi Tik Tok Sebagai Media Pembelajaran Bahasa Indonesia.” Jurnal Pendidikan Dan Pembelajaran Bahasa Indonesia 8 (2): 95-102.

Fanaqi, Chotijah. 2021. “Tiktok Sebagai Media Kreativitas Di Masa Pandemi Covid-19.” Jurnal Dakwah 22 (1): 105-30.

Firamadhina, Fadhlizha Izzati Rinanda, and Hetty Krisnani. 2021. "PERILAKU GENERASI Z TERHADAP PENGGUNAAN MEDIA SOSIAL TIKTOK: TikTok Sebagai Media Edukasi Dan Aktivisme." Share : Social Work Journal 10 (2): 199. https://doi.org/10.24198/share.v10i2.31443.

I Putu Hendika Permana, and Ni Putu Suci Meinarni. 2021. "Ratio Analysis on Tiktok (Social Media) for Qualitative Research Using Explorative Methods." Jurnal Ekonomi \& Bisnis JAGADITHA 8 (1): 30-38. https://doi.org/10.22225/jj.8.1.2944.30-38.

Nugroho, Muhammad Wahyu, Supriyono Supriyono, and Dadi Mulyadi Nugraha. 2021.

"Pemanfaatan Media Sosial Tik Tok Sebagai Sarana Penguatan Identitas Nasional Di Era Pandemi." Academy of Education Journal 12 (2): 262-74.

https://doi.org/10.47200/aoej.v12i2.695.

Priambodo, Bagus. 2018. “Pengaruh ‘Tiktok’ Terhadap Kreativitas Remaja Surabaya.” Skripsi, 74.

Wanimbo, Emiron, Selvie Tumengkol, and Juliana Tumiwa. 2021. "Jurnal Ilmiah Society” 1 (1): 110. 